\title{
Medicinal and Aromatic Plants Market in Hatay Province and Development Opportunities
}

\author{
Ahmet Duran Çelik ${ }^{1, a, *}$, Aykut Gül2,b \\ ${ }^{I}$ Department of Agricultural Economics, Faculty of Agriculture, Hatay Mustafa Kemal University, 31060 Hatay, Turkey \\ ${ }^{2}$ Department of Agricultural Economics, Faculty of Agriculture, Cukurova University, 01330 Adana, Turkey
} ${ }^{*}$ Corresponding author

\section{A R T I C L E I N F O}

Research Article

Received : 07/01/2020

Accepted : 21/02/2020

Keywords:

Medicinal and aromatic plant

Production

Processing

Hatay

Wild collection

\section{A B S T R A C T}

Hatay province has a rich ecosystem that medicinal and aromatic plants grow naturally all across the province. There are about 2.000 flowery plants in the vegetative pattern of the province, and it is around 300 of them are endemic plants. The main purpose of this study was to present the production and processing structure of medicinal and aromatic plants (MAPs) which are commonly traded in the Hatay Province of Turkey. In addition, it was aimed to examine the problems of the sector in the Province, and to bring solutions about those problems. According to the research results: in Hatay Province, MAPs are mostly collected from nature; in terms of local processing enterprises, there are problems about obtaining sufficient raw materials; and spice plants are marketed as semi-processed to the other districts. There is a lack of producer organization of MAPs in the region. In order to improve MAPs industry in the province, it is necessary to establish a MAPs coordination and management unit where all shareholders are represented. It should be focused on: extending MAPs cultivation, providing subsidies for producers and processing enterprises, developing effective marketing and publicity strategies for target markets, and establishing a MAPs research institution.

Türk Tarım - Gıda Bilim ve Teknoloji Dergisi, 8(5): 1127-1133, 2020

\section{Hatay İlinde Tıbbi ve Aromatik Bitkiler Piyasası ve Geliştirilmesi İmkânları}

\begin{tabular}{|c|c|}
\hline M A K A L E B İ L G İ S İ & Ö Z \\
\hline $\begin{array}{l}\text { Anahtar Kelimeler: } \\
\text { Tibbi ve aromatik bitki } \\
\text { Üretim } \\
\text { İsleme } \\
\text { Hatay } \\
\text { Doğadan toplama }\end{array}$ & $\begin{array}{l}\text { Hatay yöresi, tıbbi ve aromatik bitkilerin doğal olarak yayılım gösterdiği zengin bir ekosisteme } \\
\text { sahiptir. Yörede doğal olarak yetişen } 2.000 \text { civarında çiçekli bitki türü bulunurken bu türlerin } \\
\text { yaklaşık } 300 \text { tanesi endemik bitkiler sınıfında yer almaktadır. Bu çalışmada, Hatay yöresinde } \\
\text { yaygın olarak ticareti yapılan tıbbi ve aromatik bitkilerin üretimi, işlenmesinin yanı sıra sektörün } \\
\text { mevcut sorunlarının belirlenmesi ve bu sorunlara yönelik olarak çözüm önerilerinin getirilmesi } \\
\text { amaçlanmıştır. Araştırma sonuçlarına göre, Hatay yöresinde tıbbi ve aromatik bitkilerin } \\
\text { çoğunlukla doğadan toplanarak elde edildikleri, ürünleri işleyen firmaların kaliteli ve yeterli } \\
\text { miktarda hammadde temin etme konusunda sorunlar yaşadıkları, baharat amaçlı bitkilerin yarı } \\
\text { mamul olarak yöre dışına pazarlandıkları belirlenmiştir. Ayrıca yörede tıbbi ve aromatik bitkiler } \\
\text { konusunda örgütlenme ve koordinasyonun oldukça zayıf olduğu sonucuna ulaşılmı̧tır. Yörede } \\
\text { katma değeri yüksek türlerde kültürel üretimin yaygınlaştırılmasına yönelik çalışmalara ağırlık } \\
\text { verilmesi, bütün paydaşların tek bir çatı altında temsil edildiği ve ortak kararların alındığı merkezi } \\
\text { bir yönetim yapısının oluşturulması, üretici ve işleyen firmalara yönelik teşvik ve desteklerin } \\
\text { artırılması, hedef pazarlara yönelik etkili pazarlama ve tanıtım stratejilerinin geliştirilmesi ve } \\
\text { Hatay ilinde çok yönlü çalışmalar yapacak bir tıbbi ve aromatik bitkiler araştırma merkezinin } \\
\text { kurulması, sektörün yöredeki gelişimi için önem taşımaktadır. }\end{array}$ \\
\hline
\end{tabular}




\section{Giriş}

Tıbbi ve aromatik bitkiler tarih boyunca gerek tıbbi amaçlı gerekse gıda amaçlı olarak kullanılmış ve önem düzeyi giderek artmıştır. Tıbbi bitkilere ait ilk yazılı kaynaklar M.Ö.4000 yıllara, Sümerler dönemine kadar uzanmakta olup, kesin tarih bilinmemekle birlikte insanbitki ilişkisinin başlangıcının 60 bin yıl öncesine dayandığ tahmin edilirken, eski misırlılardan Hititlilere kadar, bitkilerin tıbbi amaçlı olarak kullanıldığına dair pek çok bulgu bulunmaktadır (Keykubat, 2016).

Dünya nüfusunun yaklaşık \%80'i hastalıklarının tedavisinde ilk olarak tıbbi bitkilere başvururken, Amerika Birleşik Devletleri (ABD) gibi gelişmiş ülkelerin modern tıpta kullandığı ilaçların \%25'inin etkin maddesi bitkisel kökenli olduğu bilinmektedir (Farnsworth ve ark., 1985).

Tedavi amaçlı kullanılmasının yanında, baharat, kozmetik ürünler, uçucu yağlar, bitkisel sağlık ürünleri, renklendirici boyalar, bitki koruma ürünlerin ve bu ürünlerden elde edilebilen ara ürünler gibi birçok ürünün üretiminde tıbbi ve aromatik bitkilerden faydalanılmaktadır (Lubbe ve Verpoorte, 2011).

Türkiye coğrafi konumu, iklimi, tarımsal potansiyeli, geniş yüzölçümü gibi özelliklerinden dolayı tıbbi ve aromatik bitki yetiştiriciliğine oldukça elverişlidir. Türkiye'de tıbbi ve aromatik bitkiler yoğun olarak Ege, Marmara, Akdeniz, Doğu Karadeniz ve Güneydoğu Anadolu Bölgeleri'nde yetişmekte olup, çoğunlukla doğadan toplanmak sureti ile elde edilmektedirler. Bununla birlikte, kimyon, anason, kekik, çemen, haşhaş, rezene, nane ve kişniş kültürel tarımı yapılan çeşitler arasında yer almaktadır. Defne, ıhlamur, adaçayı, biberiye, kuşburnu gibi bitkiler ise doğadan toplanmakta olup, ağırlıklı olarak Ege, Marmara, Akdeniz, Doğu Karadeniz ve Güneydoğu Anadolu Bölgelerinden elde edilmektedirler (Bayram ve ark., 2010).

Tarımı yapılan ve doğadan toplanan bu bitkiler iç ve dış ticarete konu olmaktadırlar. Türkiye'nin ihraç ettiği başlıca tıbbi ve aromatik bitkiler; haşhaş, kekik, defne yaprağı, kimyon ve anasondur. Türkiye 2018 yılında 253 milyon USD değerinde 82.876 ton tıbbi ve aromatik bitki ihracatı, 46 milyon USD değerinde 27.211 ton tıbbi ve aromatik bitki ithalatı gerçekleştirmiştir (TÜİK, 2019).

Hatay ili, tıbbi ve aromatik bitkilerin doğal olarak ve kültüre alınarak yetiştirildiği zengin bir ekosisteme sahiptir. Hatay'da doğal olarak yetişen çiçekli bitki sayısı 2.000 civarında olup bunlardan 250-300 tanesi endemik bitkiler grubunda yer almaktadır. Bu rakam, Türkiye'nin toplam endemik bitki sayısının yaklaşık \%10'unu oluşturmaktadır. Hatay florasında yer alıp, tıbbi ve aromatik bitki özelliği taşıyan bitki sayısı yaklaşık olarak 550 civarındadır (İlçim, 2014). Hatay ilinde tıbbi ve aromatik bitkilerin tarımı fazla yaygın olmayıp büyük oranda doğadan toplanmak sureti ile elde edilmektedirler. Defne, kekik, adaçayı ve sumak yörede yetişen başlıca türleridir.

Bu çalışmanın temel amacı, Hatay ilinde yaygın olarak yetişen başlıca tıbbi ve aromatik bitkilerin mevcut üretim ve pazarlama olanaklarının belirlenmesi, gerek üretim safhasında, gerekse işleme ve pazarlama safhasındaki sorunların tespit edilerek, mevcut potansiyelin daha verimli kullanılması için çözüm önerileri geliştirmektir.

\section{Materyal ve Yöntem}

Araştırmanın ana materyali, Hatay ilinde faaliyet gösteren üretici/doğadan toplayıcılara ve tıbbi ve aromatik bitkileri işleyen firmalara yönelik olarak gerçekleştirilen iki farklı anket çalışması ile elde edilen birincil verilerden oluşmaktadır. Araştırma alanı ve örnek seçimi, Hatay İl Tarım ve Orman Müdürlüğünden elde edilen kayıtlar doğrultusunda belirlenmiştir. Örnekleme yöntemi olarak yörede faaliyet gösteren üretici ve işleyen firma sayısının sınırlı olmasından dolayı tam sayım yöntemi kullanılmıştır. Buna göre, yörede üretim ve toplayıcılık faaliyetinin yoğun olarak yapıldığı Samandağ, Yayladağı, Defne, Altınözü, Kırıkhan, Hassa ve Antakya ilçelerinde toplam 106 adet kültürel üretici ve doğadan toplayıcı belirlenmiş olup, bu kişilerden bir kısmına ulaşılamadığından, bir kısmının ise görüşme talebine olumlu yanıt vermemesinden dolayı toplam 78 adet anket çalışması yapılmıştır. İşleyen işletmelere yönelik anket çalışmasında ise, yörede tıbbi ve aromatik bitkileri, uçucu yağ, kozmetik ürün, kurutma ve baharat şeklinde işleyen toplam 19 işletme belirlenmiş olup, bu işletmelerin 3 tanesi aktif olmadığından, 1 tanesi de görüşme talebine olumlu yanıt vermemesinden dolayı toplamda 15 işletme ile anket çalışması yapılmıştır. Araştırma ayrıca ikincil veriler ile de desteklenmiştir. Bu amaçla, konu hakkında daha önce Dünya'da ve Türkiye'de yapılan çalışmalar ve çeşitli kurum ve kuruluşlardan elde edilen istatistiki verilerden yararlanılmıştır.

\section{Araştırma Bulguları}

\section{Dünya'da Tıbbi ve Aromatik Bitkiler}

Tıbbi ve aromatik bitkiler, tarih boyunca sağlıklı yaşamak, hastalıkları önlemek veya iyileştirmek için kullanılmış olup, günümüzde kozmetik, beslenme, güzel koku ve tat verme gibi çeşitli diğer amaçlara da hizmet etmektedirler. Dünyada gıda amaçlı yetiştirilen bitki türü sayıs1 3.000 dolaylarında olup, yenilebilir yabani bitki türü sayıs1 10.000 civarındadır. Dünya Sağlık Örgütünün yayınladığı rapora göre, kayıtlı olan bitkisel drog (tedavi özelliği olan hammadde) sayısı 20.000 civarında olup, henüz kayıtlı olmayan bitkiler ile bu rakamın 100.000 civarında olduğu tahmin edilmektedir (Hatay İl Tarım ve Orman Müdürlüğü, 2015). Kayıtlı olan tıbbi ve aromatik bitkilerden 4.000 tanesi yaygın olarak kullanılmakta olup, dünyada 2.000, batı Avrupa da ise 500 kadar tıbbi bitki türünün ticareti yapılmaktadır (BAKA, 2012).

Lubbe ve Verpoorte (2011), tıbbi ve aromatik bitkilerin başlıca kullanım alanlarını şu şekilde sıralamıştır;

- Tedavi amaçlı ilaçlar

- Kozmetik ürünler

- Uçucu bitkisel yağlar

- Bitkisel sağlık ürünleri

- Renklendirici boyalar

- Bitki koruma ürünleri

Dünya üzerinde bilinen toplam bitki tür sayısı 422.000 olup, bu türlerin 72.000 adedi tıbbi bitki türlerinden oluşmaktadır. Tıbbi bitki türlerinin ülkeler bazında dağılımında, 4.941 bitki türü ile Çin ilk sırada, 3.000 bitki türü ile Hindistan ikinci sırada ve 2.564 bitki türü ile ABD üçüncü sırada gelmektedir (Çizelge 1). 
Çizelge 1. Dünyada tıbbi bitki tür sayıları ve oranları

Table 1. The number of medicinal and aromatic plant species in the world

\begin{tabular}{l|rrr}
\hline \multicolumn{1}{c|}{ Ülkeler } & Bitki Tür Sayıs1 & Tibbi Bitki Tür Sayıs & Oran (\%) \\
\hline Çin & 32.200 & 4.941 & 15,34 \\
Hindistan & 18.664 & 3.000 & 16,07 \\
ABD & 21.641 & 2.564 & 11,85 \\
Vietnam & 10.500 & 1.800 & 17,14 \\
Tayland & 11.625 & 1.800 & 15,48 \\
Pakistan & 4.950 & 1.500 & 30,30 \\
Malezya & 15.500 & 1.200 & 7,74 \\
Kore & 2.898 & 1.000 & 34,51 \\
Nepal & 6.973 & 900 & 12,91 \\
Fransa & 4.630 & 900 & 19,44 \\
Flipinler & 8.931 & 850 & 9,52 \\
Bulgaristan & 3.567 & 750 & 21,03 \\
Sri Lanka & 3.314 & 550 & 16,60 \\
Ürdün & 2.100 & 363 & 17,29 \\
Macaristan & 2.214 & 270 & 12,20 \\
\hline Dünya & 422.000 & 72.000 & 17,06 \\
\hline
\end{tabular}

Kaynak: Schippman ve ark. (2006)

Çizelge 2. Türkiye'de kültürel üretimi yapılan bazı tıbbi ve aromatik bitkiler

Table 2. Medicinal and aromatics plants cultivation in Turkey

\begin{tabular}{l|rrrrrr}
\hline \multirow{2}{*}{ Bitki Adı } & \multicolumn{2}{|c}{2005} & \multicolumn{2}{c}{2017} & \multicolumn{2}{c}{2018} \\
\cline { 2 - 7 } & Alan (da) & Üretim (ton) & Alan (da) & Üretim (ton) & Alan (da) & Üretim (ton) \\
\hline Haşhaş & 253.350 & 13.644 & 237.314 & 15.244 & 451.226 & 26.991 \\
Kimyon & 258.000 & 14.300 & 267.358 & 19.175 & 361.761 & 24.195 \\
Kekik & 47.000 & 6.400 & 121.472 & 14.477 & 139.061 & 15.895 \\
Gül (Yağlık) & - & - & 33.277 & 13.372 & 34.205 & 14.773 \\
Nane & 8.710 & 7.750 & 10.520 & 14.213 & 10.134 & 14.511 \\
Anason & 165.000 & 9.500 & 121.833 & 8.418 & 124.455 & 8.664 \\
Çörekotu & - & - & 32.560 & 3.094 & 33.864 & 3.322 \\
Rezene & - & - & 16.525 & 2.022 & 23.400 & 3.067 \\
Şerbetçiotu & 2.530 & 1.280 & 3.300 & 1.785 & 3.300 & 1.785 \\
Lavanta & - & - & 6.606 & 845 & 8.684 & 1.040 \\
Adaçay1 & - & - & 4.123 & 557 & 3.951 & 428 \\
Oğulotu & - & - & 207 & 106 & 172 & 84 \\
\hline Toplam & 734.590 & 52.874 & 855.095 & 93.308 & 1.194 .213 & 114.755 \\
\hline
\end{tabular}

Kaynak: TÜiK, 2019.

\section{Türkiye'de Tıbbi ve Aromatik Bitkiler Üretimi}

Türkiye florasında 174 familyaya ait, 1.251 cins ve 12.000 civarında bitki türü vardır. Aktarlarda ticari olarak satılan bitki türü sayısı 200 kadar olup dış ticarete konu olan bitki sayısının ise 100 civarında olduğu bilinmektedir (Kırıc1, 2015).

Türkiye'de tıbbi ve aromatik bitkiler doğadan toplama, kültürel üretim ve organik üretim olmak üzere üç şekilde elde edilmektedir.

\section{Doğadan Toplama Yolu ile Üretim}

Türkiye'de tıbbi ve aromatik bitkiler çoğunlukla doğadan toplama yolu ile elde edilmektedir. Söz konusu bitkiler ülke genelinde yaklaşık 165 bin hektar alana yayılmıştır (FIBL ve IFOAM, 2013). Türkiye'de doğadan toplama sureti ile elde edilip, iç ve diş ticarete konu olan toplam bitki sayısı 347'dir. Bunların yaklaşık \%11'i (35 tanesi) endemik bitkilerdir (Kırıcı, 2015). Tıbbi ve aromatik bitkiler, Türkiye'nin hemen hemen her bölgesinde doğada yaygın olarak yetişmekte olup, defne, ıhlamur, adaçayı, biberiye, kuşburnu gibi bitkiler doğadan toplanmak sureti ile elde edilen başlıca bitkilerdir (Bayram ve ark., 2010).

\section{Kültürel Üretim}

Türkiye'de tıbbi ve aromatik bitkilerin kültürel üretimine yönelik çalışmalar son yıllarda yoğunlaşmıştır. Özellikle tarım politikalarında yapılan değişiklikler sonucu, üretim alanlarında daralma yaşanan tütün bitkisinin yerine alternatif olarak kekik gibi tıbbi ve aromatik bitkiler yetiştirilmeye başlanmıştır (Kapluhan, 2013). Türkiye, kekik üretiminde önemli bir yere sahip olup, dünya kekik ihracatında ilk sırada yer almaktadır. Kekik bitkisi doğadan yaygın olarak toplanmakla birlikte, yaklaşık 121 bin dekarlık alanda kültürel olarak üretilmektedir. Kekik ekiliş alanı ve üretim miktarı açısından Denizli ili ilk sırada gelirken, Manisa, Muğla, Uşak ve Hatay diğer önemli kekik üreticisi illerdir (Kırıc1, 2015; TÜİK, 2019).

2018 y1lı itibariyle, Türkiye'de kültürel olarak üretimi yapılan başlıca tıbbi ve aromatik bitkiler şu şekildedir; üretim miktarı olarak 26.991 ton ile haşhaş ilk sırada gelirken, bunu sirasiyla kimyon (24.195 ton), kekik (15.895 ton), yağlık gül (14.773 ton) ve nane (14.511 ton) takip etmektedir. Üretim alanı olarak ise sırasıyla haşhaş (451.226 da), kimyon (361.761 da), kekik (139.061 da) ve anason (124.455 da) en geniş üretim alanına sahip bitkilerdir (Çizelge 2). 


\section{Organik Üretim}

Son yillarda, organik bitki ve droglara yoğun bir talep artışı yaşanmaktadır. Gıda dışı ürünler grubunda yer alan gül kurusu, gül yağı, gül suyu ve lavanta yağı gibi bitkiler özellikle kozmetik ve ilaç sanayinde hammadde olarak kullanılan organik ürünlerden bazılarıdır (Bayram ve ark., 2010).

Türkiye'de yirmi civarında ilde organik olarak tıbbi ve aromatik bitki üretimi yapılmaktadır (Faydaoğlu ve Sürücüoğlu, 2011). Kuşburnu, keçiboynuzu, kekik, mersin, gül, adaçayı, defne ve haşhaş bitkileri, Türkiye'de organik olarak üretilen başlıca tıbbi ve aromatik bitkilerdir. Söz konusu bitkilerin büyük çoğunluğu hem doğadan toplama hem de kültürel üretim yolu ile elde edilirken, haşhaş, rezene, gül, anason ve kimyon gibi bitkiler sadece kültürel üretim yolu ile elde edilmektedirler (Çizelge 3).

Hatay Yöresinde Tıbbi ve Aromatik Bitkiler Üretimi

Araştırma alanında, tıbbi ve aromatik bitki üretim ve toplayıcılık faaliyetinin yoğun olarak yapıldığı Samandağ, Yayladağı, Defne, Altınözü, Kırıkhan, Hassa ve Antakya ilçelerinde toplam 78 adet anket çalışması yapılmıştır (Çizelge 4).
Araștırma alanında, doğadan toplama ve kültürel üretim yolu ile elde edilen tıbbi ve aromatik bitki miktarları Çizelge 5 'te verilmiştir. Yörede üretilen ürünler arasında defne yaprağ 78,9 ton ile ilk sırada gelirken, zahter kekik 47,6 ton ile ikinci, çörekotu 9,3 ton ile üçüncü, adaçayı 6,3 ton ile dördüncü sirada gelmektedir. Bunun haricinde, 3,5 ton sumak, 2,2 ton Halil İbrahim zahteri (Satureja Thymbra), 40 $\mathrm{kg}$ lavanta ve $1,8 \mathrm{~kg}$ safran üretilmiştir. Ayrıca doğadan toplama yolu ile $415 \mathrm{~kg}$ diğer tıbbi ve aromatik bitkiler (peryavşan otu, fesleğen, çoban çökerten, karabaş otu, kantaron, deve dikeni tohumu, pelin otu, biberiye, oğulotu, şahtere otu, civanperçemi, çakşır, 1şkın kökü, çakal otu) elde edilmiştir. Araştırma kapsamında yörede toplam 148.848 ton tıbbi ve aromatik bitki üretildiği belirlenmiştir.

Tıbbi ve Aromatik Bitkileri İşleyen İşletmelere Ait Araştırma Bulguları

Araştırma alanında tıbbi ve aromatik bitkileri işleyen toplam 15 işletme ile anket çalışması yapılmıştır. İşletmelerin ilçelere göre dağılımı, Antakya ilçe merkezinde 10 adet $(\% 66,67)$, Samandağ ilçesinde 2 adet $(\% 13,33)$, Yayladağı ilçesinde 2 adet $(\% 13,33)$ ve Kırıkhan ilçesinde 1 adet $(\% 6,67)$ olacak şekildedir (Çizelge 6$)$.

Çizelge 3. Türkiye'de organik olarak üretilen tıbbi ve aromatik bitkiler (2017)

Table 3. Organic medicinal and aromatic plants production in Turkey (2017)

\begin{tabular}{|c|c|c|c|c|c|}
\hline Bitki Ad1 & Üretim (ton) & Oran $(\%)$ & Doğadan Toplama (ton) & Oran $(\%)$ & Toplam (ton) \\
\hline Kuşburnu & 221,06 & 11,20 & $1.754,25$ & 88,80 & $1.975,31$ \\
\hline Keçiboynuzu & $1.031,16$ & 69,85 & 445,10 & 30,15 & $1.476,26$ \\
\hline Kekik & 636,86 & 46,68 & 727,38 & 53,32 & $1.364,24$ \\
\hline Mersin & 378,16 & 49,87 & 380,15 & 50,13 & 758,31 \\
\hline Gül (Yağlık) & 604,89 & 100 & - & - & 604,89 \\
\hline Adaçayı & 283,52 & 58,67 & 199,69 & 41,33 & 483,21 \\
\hline Defne & 140,99 & 44,35 & 176,92 & 55,65 & 317,91 \\
\hline Haşhaş & 320,22 & 100 & - & - & 320,22 \\
\hline Yaban mersini & 23,47 & 11,77 & 176,00 & 88,23 & 199,47 \\
\hline Anason & 168,21 & 100 & - & & 168,21 \\
\hline Rezene & 146,19 & 100 & - & & 146,19 \\
\hline Kimyon & 105,39 & 100 & - & & 105,39 \\
\hline Karahan & - & - & 100,00 & 100 & 100,00 \\
\hline Nane & 39,26 & 55,09 & 32,00 & 44,91 & 71,26 \\
\hline Biberiye & 63,13 & 96,93 & 2,00 & 3,07 & 65,13 \\
\hline Lavanta & 27,33 & 100 & - & - & 27,33 \\
\hline Reyhan & 19,43 & 100 & - & - & 19,43 \\
\hline Kapari & 8,58 & 100 & - & - & 8,58 \\
\hline Sumak & 5,53 & 100 & - & - & 5,53 \\
\hline Tarhun & 3,00 & 100 & - & - & 3,00 \\
\hline Toplam & $4.226,38$ & 51,42 & $3.993,49$ & 48,58 & $8.219,87$ \\
\hline
\end{tabular}

Kaynak: Tarım ve Orman Bakanlığı, 2019.

Çizelge 4. Araştırma alanında görüşülen üreticilerin ilçelere göre dağılımı Table 4. Distribution of the producers in the research area by districts

\begin{tabular}{|c|c|c|c|c|}
\hline \multirow{2}{*}{ İlçe } & \multicolumn{2}{|c|}{ Frekans } & \multirow{2}{*}{ Toplam } & \multirow{2}{*}{ Oran $(\%)$} \\
\hline & Kültürel Üretici & Doğadan Toplayıcı & & \\
\hline Samandağ & 2 & 18 & 20 & 25,60 \\
\hline Altınözü & 19 & 0 & 19 & 24,40 \\
\hline Defne & 7 & 9 & 16 & 20,50 \\
\hline Yayladağ1 & 12 & 4 & 16 & 20,50 \\
\hline Hassa & 3 & 1 & 4 & 5,10 \\
\hline Antakya & 2 & 0 & 2 & 2,60 \\
\hline Kirıkhan & 1 & 0 & 1 & 1,30 \\
\hline Toplam & 46 & 32 & 78 & 100,00 \\
\hline
\end{tabular}


Çizelge 5. Araştırma alanında tıbbi ve aromatik bitkiler üretim miktarı

Table 5. Production amounts of medicinal and aromatic plants in the research area

\begin{tabular}{l|cc}
\multicolumn{1}{c|}{ Ürün } & Üretici Sayısı (*) & Toplam Üretim Miktarı (kg) \\
\hline Defne Yap. (Dallı) & 17 & 72.900 \\
Defne Yap. (Ayıklanmış) & 6 & 6.015 \\
Kekik (Zahter) & 24 & 47.630 \\
Çörekotu & 2 & 9.350 \\
Adaçayı & 7 & 6.350 \\
Sumak (Dallı) & 11 & 3.522 \\
Halil İbrahim Zahteri & 4 & 2.260 \\
Lavanta & 2 & 40 \\
Safran & 6 & 1,8 \\
Diğerleri & 3 & 415 \\
\hline Toplam & 82 & 148.484 \\
\hline *Üreticiler birden fazla üründe üretim faaliyeti gösterebilmektedir & &
\end{tabular}

*Üreticiler birden fazla üründe üretim faaliyeti gösterebilmektedir.

Çizelge 6. İşletmelerin ilçelere göre dağılımı

Table 6. Distribution of the enterprises by districts

\begin{tabular}{l|cc}
\hline \multicolumn{1}{c|}{ İlçe } & Frekans & Oran $(\%)$ \\
\hline Antakya & 10 & 66,67 \\
Samandağ & 2 & 13,33 \\
Yayladağ1 & 2 & 13,33 \\
Kirkhan & 1 & 6,67 \\
\hline Toplam & 15 & 100,00 \\
\hline
\end{tabular}

Çizelge 7. İşletmelerin faaliyet alanları

Table 7. Activity fields of the enterprises

\begin{tabular}{l|cc}
\multicolumn{1}{c|}{ Faaliyet Alanı } & Frekans & Oran $(\%)$ \\
\hline Sabun ve Kozmetik & 7 & 46,67 \\
Kurutma Fabrikası & 4 & 26,66 \\
Uçucu yağ & 1 & 6,67 \\
Baharat & 3 & 20,00 \\
\hline Toplam & 15 & 100,00 \\
\hline
\end{tabular}

İşletmelerin faaliyet alanlarına göre dağılımları Çizelge 7'de verilmiştir. İşletmelerin \%46,67'si sabun ve kozmetik ürünleri üreten işletmelerden oluşurken, \%26,66'sı kurutma fabrikası, \%6,67'si uçucu yağ fabrikası ve \%20,00'si baharat fabrikalarıdır. Araştırma alanında toplam 4 adet uçucu yağ fabrikası bulunurken, bu fabrikalardan sadece 1 tanesi aktif haldedir. Sabun/kozmetik ve baharat fabrikaları Antakya ilçe merkezinde yer alırken, kurutma fabrikalarının 2 tanesi Samandağ, 2 tanesi Yayladağı ilçelerinde, uçucu yağ fabrikası ise Kırıkhan ilçesinde bulunmaktadır.

Araştırma kapsamında incelenen işletmelerin işledikleri

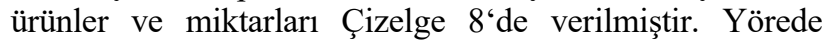
toplayıcılığ yaprağının 4 adet kurutma fabrikasında kurutulması sureti ile elde edilen toplam ürün miktarı 4.775 ton olup, işletme başına yılda ortalama 1.194 ton kuru defne yaprağı elde edilmektedir. Kurutma fabrikalarında defne yaprağının haricinde, kekik, adaçayı, biberiye, çakşır, karabaş, kantaron, at kuyruğu, mersin yaprağı gibi diğer bitki türleri de işlenmektedir. Kurutma fabrikalarında işlenen ürünlerin büyük çoğunluğu yöre içerisinden temin edilirken, sınırl miktarda da olsa çevre illerden veya Suriye, Gürcistan gibi ülkelerden ithalat yolu ile elde edilen ürünlerde işlenerek pazara sunulmaktadır.

Araştırma kapsamında görüşülen 7 adet sabun ve kozmetik fabrikasında, defne yağının işlenmesi sureti ile yilda 1.739 ton defne sabunu üretildiği belirlenmiştir. Defne sabunun haricinde, çeşitli bitkisel sabunlar, şampuan ve çeşitli kozmetik ürünlerde üretilmektedir. Defne sabununun hammaddesi olan defne yağı yöre içerisinden temin edilirken, diğer kozmetik ürünlerin üretimi için gerekli olan uçucu yağlar ise yöre dışından temin edildiği tespit edilmiştir.

Yörede aktif olarak faaliyette olan 1 adet uçucu yağ fabrikasında, yılda toplam 3,8 ton defne eterik yağ üretildiği belirlenmiştir. Defne eterik yağı, defne sabunu üretiminde kullanılan defne tohumunun yağından farklı olup, daha çok ilaç ve kozmetik sanayilerinde hammadde olarak kullanılan ve maddi değeri defne yağına göre çok daha yüksek bir yağ türüdür.

Araştırma kapsamında görüşülen 3 adet baharat firması tarafından, kimyon, karabiber, kırmızıbiber, çörekotu, kekik, susam gibi baharatlar başta olmak üzere, çeşitli ürünler paketlenerek iç pazara sürülmektedir. Baharat firmalarının işledikleri ürünler Hatay yöresinden elde edilmeyip, tamamına yakın bir kısmı ithalatçı firmalar kanalı ile temin edilen, düşük maliyetli baharat türlerinden oluşmaktadır.

\section{Hatay Yöresinde Tıbbi ve Aromatik Bitkiler} Sektörünün Sorunları

Araştırma sonuçlarına göre, yörede tıbbi ve aromatik bitkilerin genel olarak doğadan toplama yolu ile elde edildiği ve kültürel üretimin sınırlı olduğu belirlenmiştir. Bunun yanı sıra üreticilerin tıbbi ve aromatik bitki üretiminden elde 
ettikleri gelirin geçimlerini sağlamaya yetmediği, geçimlerini sağlamak üzere diğer tarımsal ve tarım dişı faaliyetler ile uğraştıkları ve doğadan toplama esnasında doğal alanların tahrip edildiği araştırmada elde edilen başlıca sorunlardır. Herhangi bir üretici örgütlenmesinin olmadığ yörede, alıcı sayısının az olmasından dolayı üretici fiyatları piyasa fiyatlarına göre oldukça düşük seyrederken, tıbbi ve aromatik bitki ticaretinden daha çok aracılık yapan tüccarların kar elde ettiği belirlenmiştir.

Tıbbi ve aromatik bitkileri işleyen işletmeler açısından karşılaşılan en önemli sorunlar ise, yeterli ve kaliteli hammaddeye ulaşımda yaşanan aksaklıklar, buna bağlı olarak kapasite kullanım oranının düşmesi, yeterli sayıda kalifiye işçinin olmaması ve zayıf pazarlama ağı olarak sıralamak mümkündür.

Hatay ilinde, tıbbi ve aromatik bitkiler sektöründe önemli bir yere sahip olan defne sabunu özelinde ise, tağşiş ve merdiven altı üretim sektörün en önemli sorunlarındandır.

Tıbbi ve aromatik bitkiler sektörünün yöredeki bir diğer önemli sorunu ise, söz konusu ürünlerin 1slahı, üretimi, işlenmesi ve pazarlanması gibi süreçlerin yönetimine yönelik bir koordinasyonun bulunmamasıdır. Çeşitli kamu ve özel kuruluşlar birbirlerinden bağımsız çabalar göstermekte ve yörenin potansiyelinden etkin şekilde yararlanılamamaktadır.

Çizelge 8. Araştırma alanında işlenen ürünler ve miktarları

Table 8. The amount of processed medicinal and aromatic plants in the research area

\begin{tabular}{|c|c|c|c|c|}
\hline İşlenen Ürün(*) & İşletme Sayısı & $\begin{array}{l}\text { Toplam Üretim } \\
\text { (ton/y1l) }\end{array}$ & $\begin{array}{l}\text { Ortalama Üretim } \\
\text { (ton/y1l) }\end{array}$ & İşletme Türü \\
\hline Defne Yaprağ 1 & 4 & $4.775,00$ & $1.193,70$ & \multirow{7}{*}{ Kurutma Fabrikası } \\
\hline Adaçayı & 3 & 54,00 & 18,00 & \\
\hline Kekik & 3 & 50,00 & 16,70 & \\
\hline Çakşır otu & 2 & 15,00 & 7,50 & \\
\hline Mersin & 1 & 7,00 & 7,00 & \\
\hline Biberiye & 1 & 4,00 & 4,00 & \\
\hline Kantaron & 1 & 3,00 & 3,00 & \\
\hline Defne Sabunu & 7 & $1.739,00$ & 248,40 & \multirow{3}{*}{$\begin{array}{c}\text { Sabun ve Kozmetik } \\
\text { Fabrikası }\end{array}$} \\
\hline Lavanta Sabunu & 3 & 33,00 & 11,00 & \\
\hline Defne Yağ1 & 1 & 1,20 & 1,20 & \\
\hline Defne Uçucu (Eterik) Yağ1 & 1 & 3,80 & 3,80 & Uçucu Yağ Fabrikası \\
\hline Kimyon & 3 & 36,00 & 12,00 & \multirow{8}{*}{ Baharat Fabrikası } \\
\hline Karabiber & 3 & 30,00 & 10,00 & \\
\hline Sumak & 3 & 19,00 & 6,30 & \\
\hline Kirmizı Biber & 3 & 14,00 & 4,70 & \\
\hline Kekik & 3 & 13,00 & 4,30 & \\
\hline Nane & 2 & 12,00 & 6,00 & \\
\hline Çörekotu & 1 & 10,00 & 10,00 & \\
\hline Susam & 1 & 5,00 & 5,00 & \\
\hline Diğerleri & 9 & 292,00 & 32,40 & \\
\hline
\end{tabular}

\section{Sonuç ve Öneriler}

Araştırma sonuçlarına göre, Hatay yöresinde tıbbi ve aromatik bitkilerin genel olarak doğadan toplama yolu ile elde edildiği ve kültürel üretimin sınırlı olduğu, tıbbi ve aromatik bitki ticaretinden daha çok büyük tüccarların kar elde ettiği sonucuna ulaşılmıştır.

İşleyen işletmeler açısından, yeterli ve kaliteli hammaddeye ulaşmada aksaklıklar yaşandığı, buna bağ $\mathrm{l}_{1}$ olarak kapasite kullanım oranlarının düşük olduğu, pazarlama ağının zayıf olmasından dolayı, ürünlerin yurtiçi ve yurt dışı pazarlara arzı konusunda sıkıntılar yaşandığı belirlenen başlıca sorunlardır. Ayrıca tağşiş ve merdiven altı üretimden dolayı sektörün imajı zedelenmektedir.

Sektörde işbirliğinin ön plana çıkarıldığı ve tüm paydaşların katılımı ile ortak kararların alındığı bir yönlendirme kurulunun oluşturulması; yöre iklimine uygun ve katma değeri yüksek ürünlerin üretimi teşvik edilerek, kültürel yetiştiriciliğin yaygınlaştırılması; çok sayıda alıcı ile üreticilerin serbest şartlarda buluştuğu bir tıbbi ve aromatik bitkiler ticaret borsasının kurulması veya mevcut ticaret borsasının kotasyon listesine başta defne yaprağı ve zahter kekik olmak üzere, tıbbi ve aromatik bitkilerin dahil edilmesi; yörede kooperatifleşmenin teşvik edilmesi; kültürel üretim, yabani türlerin ıslahı, pazarlama, AR-GE, teknik destek gibi çok yönlü çalışmalar yapacak bir araştırma merkezinin kurulması; doğal alanların tahribatının önlenmesi amacı ile, toplayıcılık ile uğraşan köylülerin toplayıcılık konusunda eğitim çalışmalarına ağırlık verilmesi; işleme sanayisi açısından, işletme kuruluşu, makine ve teçhizat alımı ve ürünlerin pazarlanması gibi konularda teşvik ve desteklemelere ağırlık verilmesi, yöredeki tıbbi ve aromatik bitkiler sektörünün gelişimine büyük katkılar sağlayacaktır.

\section{Bilgi}

Bu çalışma aynı başlıklı doktora tezinden üretilmiştir.

\section{Kaynaklar}

BAKA. 2012. Tibbi ve Aromatik Bitkiler Sektör Raporu. Batı Akdeniz Kalkınma Ajansı. Erişim: https://www.baka.org.tr /uploads/1357649536tibbi-ve-Aromatik-Bitkiler-sektorraporu-5aralik.pdf, Erişim Tarihi: 15.05.2018. 
Bayram E, Kırıcı S, Tansı S, Yılmaz G, Arabacı O, Kızıl S, Telci D. 2010. Tibbi ve Aromatik Bitkiler Üretiminin Arttırılması Olanakları. Türkiye Ziraat Mühendisliği VII.Teknik Kongresi Bildiriler Kitab1, 11-15 Ocak, ANKARA, 437-456.

Farnsworth NR, Akerele O, Bingel AS, Soejarto DD, Guo Z. 1985. Medicinal Plants in Therapy. Bulletin of the World Health Organization, 63 (6): 965-981.

Faydaoğlu E, Sürücüoğlu MS. 2011. Geçmisten Günümüze Tıbbi ve Aromatik Bitkilerin Kullanılması ve Ekonomik Önemi. Kastamonu Üni., Orman Fakültesi Dergisi, 11 (1): 52 - 67.

FIBL, IFOAM. 2013. "The World of Organic Agriculture, Statistics \& Emerging Trends 2013", FIBL-IFOAM Report, ITC, Geneva. Erişim: http://orgprints.org/26322/1/1606organic-world-2013.pdf. Erişim Tarihi: 18.06.2017.

Hatay İl Tarım ve Orman Müdürlügü. 2015. Hatay İli Tibbi ve Aromatik Bitkiler Eylem Planı (2015-2019), Hatay, 106s.

İlçim A. 2014. Hatay’ın Sessiz Güzelleri 900 Yabani Bitki, Hatay Bitki Envanteri. Hatay Valiliği.

Kapluhan E. 2013. Bekilli'de (Denizli) Alternatif Ziraat Faaliyetlerine Bir Örnek: Kekik Yetiştiriciliği. Marmara Coğrafya Dergisi, Sayı: 28, s.194-210.
Keykubat B. 2016. Tıbbi Aromatik Bitkiler ve İyi Yaşam. İzmir Ticaret Borsası. Erişim:http://itb.org.tr/dosya/rapordosya /tibbi-aromatik-bitkiler-ve-iyiyasam.pdf? $v=1506816000032$, Erişim Tarihi: 15.03.2018.

Kırıcı S. 2015. Türkiye'de Tibbi ve Aromatik Bitkilerin Genel Durumu. TÜRKTOB, Türkiye Tohumcular Birliği Dergisi, Y11:4, Say1:15, 4-11.

Lubbe A, Verpoorte R. 2011. Cultivation of Medicinal and Aromatic Plants for Specialty Industrial Materials. Industrial Crops and Products, 34: 785-801.

Schippmann U, Leaman LJ, Cunningham AB. 2006. A Comparisonof cultivation and Wild Collection of Medicinal and Aromatic Plants Under Sustainability Aspects. Medicinal and Aromatic Plants, 75-95.

Tarım ve Orman Bakanlığı, 2019. T.C. Tarım ve Orman Bakanlığı Kayıtları. Erişim: https://www.tarimorman.gov.tr /Konular/Bitkisel-Uretim/Organik-Tarim/Istatistikler, Erişim Tarihi: 13.03.2019.

TÜİK. 2019. Türkiye İstatistik Kurumu Veri Taban1. 